\title{
Performance Modeling of Kaligawe Road in Semarang Using Markov Chains
}

\author{
Sulistyowati $^{1}$, Soehartono ${ }^{2}$ \\ Fakultas Teknik, Universitas Pandanaran, Semarang \\ email: ${ }^{1}$ Sulistyowati12@unpand.ac.id, ${ }^{2}$ soehartono.sipil@ymail.com
}

\begin{abstract}
There are two kinds of pavement performance modeling, deterministic and stochastic. Among the stochastic modeling, Markov Chains receives a considerable attention ( PerezAcebo et al. 2017 ). Modeling pavement performance using Markov Chains were about developing Transition Probability Matrix (TPM) and present state vector. A model then can be developed by multiplying these two factors. This paper aimed to model pavement performance of a rigid pavement road. The object was Kaligawe road. Kaligawe road is in the northern part of the city of Semarang. It is a $6 \mathrm{~km}$ long and 15 meter wide road, divided into two lanes. There were two pavement performance models in this paper; the first one compared the real IRI data and the predicted one. The second model predicted IRI values using July'17 IRI data for the next two cycle times. The first model suggested a new IRI data should be used if there was a Maintenance and Rehabilitation work (M\&R work) before. The second model showed that the accuracy of the prediction was not reach $100 \%$, it can be seen from the gap between the real total number of no $M \& R$ work section and the predicted one.
\end{abstract}

Keywords :PavementPerformanceModeling; RigidPavement; MarkovChains

\begin{abstract}
Abstrak
Terdapat dua macam pemodelan, yaitu deterministic dan stokastik. Diantara pemodelan stokastik, Rantai Markov mendapatkan perhatian yang cukup luas (Perez-Acebo et al. 2017 ). Pemodelan kinerja perkerasan jalan menggunakan Rantai Markov dilakukan dengan pengembangan Matriks Probabilitas Transisi (TPM) dan vektor kondisi pada saat data diambil. Sebuah model didapatkan dengan mengalikan kedua faktor tersebut. Penelitian ini bertujuan memodelkan kinerja sebuah jalan berjenis perkerasan kaku. Obyek penelitian adalah jalan Kaligawe yang berada di bagian utara kota Semarang, jalan ini memiliki panjang $6 \mathrm{~km}$ dan lebar 15 meter dan terbagi menjadi dua jalur.Terdapat dua jenis pemodelan dalam penelitian ini; pemodelan pertama bertujuan membandingkan nilai IRI yang didapat di lapangan dengan nilai IRI prediksi; pemodelan kedua bertujuan untuk memprediksi nilai IRI untuk dua tahap berikutnya. Hasil analisis pemodelan pertama memberikan saran untuk mengambil nilai IRI baru dari lapangan segera setelah adanya pekerjaan perawatan dan pemeliharaan jika ingin membuat prediksi nilai IRI untuk tahap berikutnya. Pada model kedua didapat kesimpulan, bahwa hasil prediksi tidak tepat 100\%, hal ini diketahui dari perbedaan jumlah total bagian yang tidak mendapatkan pekerjaan perawatan dan pemeliharaan dengan jumlah total bagian yang sama dari hasil prediksi.
\end{abstract}

Kata Kunci : Pemodelan Kinerja Perkerasan; Perkerasan Kaku; Rantai Markov 


\section{Introduction}

A road as a public infrastructure has to always maintain its performance, not only because of its role as a primary part of transportation system, but also because road's performance is very important according to riding safety.

In order to maintain road's performance, a well planned maintenance is important especially due to resource limitation. Pavement Management Systems (PMS) are used by highway administrations for managing, planning, allocating budget and maintaining activity program (PerezAceboet al. 2017). One of the elements of the PMS is future pavement condition prediction by means of performance model. By modeling pavement performance we predict the pavement condition in advance to make appropriate maintenance plan.

There are many pavement performance models that can be developed for pavement performance (Perez-Acebo et al. 2017). The deterministic and probabilistic models are the most employed and they are generally referred as the fundamental groups (Hong and Wang 2003). Deterministic models are used if historical condition data of an index or indices are available. On the contrary, probability based models provide the probabilistic of the expected variable, not a precise value; the stochastic ones can introduce uncertainty in pavement performance, which is said to be probabilistic in nature (Golroo and Tighe 2009).

In probabilistic modeling, Markov Chains receives a lot of attention from researchers to model infrastructure performance (Baik et al. 2006). These models need establishing a series of condition states and time periods. Moreover Perez-Acebo et al. 2017 explained the theory about transition probability matrix in conjunction with modeling road performance.

This paper aimed to develop a transition probability matrix and predict the performance of Kaligawe Road in the city of Semarang by means of homogenous Markov Chains. The data used are the roughness data that were taken every semester by the road authority, Central Java Bina Marga National Road Planning and Monitoring Work Unit with the data ranging from June'16 to December' 17.

The developed transition probability matrix and the prediction pictured and predicted the deterioration rate of the road; it means that only data that reflected road decreasing condition were taken into account.

According to Sheskin (2011), in developing a Markov Chain model, an engineer must assume but cannot prove that a process possesses the Markov Property. In accordance with Sheskin, Markov property assumes the simplest kind of dependency, that given the present state of a random process, the conditional probability of the next state depends only on the present state, and is independent of the past history of the process, furthermore he states that this simplification has enabled engineers and managers to develop mathematically tractable models that can be used to analyze a variety of physical, economic and social systems. Still according to Sheskin, a random process that lacks the Markov Property is one for which knowledge of its past history is needed to probabilistically model its future behavior.

In accordance with Grassmann et. al 1985, transition probabilities can be estimated by counting the transitions among states over a long period of time. In his book, Sheskin gives an example of a sequential inspection process, i.e. every hour a quality inspector either accepts a product, 
sends it back to be reworked or rejects it. The inspector's goal is to construct a Markov Chain model of product quality.

\section{Materials and Methods}

The performance of rigid pavement road is measured by its roughness. Many road administrations use roughness to measure riding quality and to identify where maintenance and rehabilitation (M\&R) activities must be done (Katthaket al. 2014). The standard measurement for road roughness is known widely as the International Roughness Index (IRI).

Prior to the development of transition probability matrix, there were some information about the Kaligawe road that would be used in developing the TPM, they were :

1. Road type :Kaligawe road is rigid pavement road with 6 kilometer length and 15 meter wide road, lies on the northern part of Semarang. This road is one of the primary roads that connects Semarang and Demak; it is also a main road to the province of Jawa Timur.

The sub base of this road is class A aggregate, where on top of it lies 10 centimeter thickof lean concrete, then 31 centimeter thick of concrete as a structure on top of the lean concrete. The main structureof the road was high quality concrete with FS 45 which could be employed in three to seven days after pouring.

2. Cycle time: Bina Marga as a road administrator uses IRI value to check road serviceability. Kaligawe road is under the authority of the Bina Marga of JawaTengah .The IRI data were taken every six month or every semester. In order to develop a transition probability matrix and predict the road performance, data from two consecutive years were used. They are data in June'16, December'16, July'17 and December' 17.

\section{Number of Condition States}

The IRI value data from the Bina Marga were varied with the range from 2 to 12 . They were the IRI values per 100 meter long and 7.5 meter wide. As mentioned above that Kaligawe road has two lanes, these IRI data were the data from one of the lanes. These data were then grouped into some categories as stated in Table 1.

4. Maintenance and Rehabilitation (M\&R) Works

Maintenance works on Kaligawe Road wereusually joint resealing and joint load restoring. Aside the heavy traffic load, the road also has to deal with flood. Flood usually happened on this road because rain water cannot flow easily from the road as the drain often fulfilled with sea water; it was because of the sea water intrusions. According to that condition, the rehabilitation work was also level uprising.

To establish condition state of a road, usually, IRI values were classified to a certain condition. In IRI values, a value near 0 represents perfection with ascending values represents worse road condition, i.e. 1.5 to $2.0 \mathrm{~m} / \mathrm{km}$ represents a very good condition, $10 \mathrm{~m} / \mathrm{km}$ represents damage condition and values over $12.0 \mathrm{~m} / \mathrm{km}$ represents unpaved road or failed (Adedimila et al. 2009 and Perez-Acebo et al. 2017). Using the classification of condition states of IRI values stated, Table 1 was established by using the range of 2 $\mathrm{m} / \mathrm{km}$ of IRI values to determine the condition states of Kaligawe road.

Table 2 is the IRI data examples on June 2016 that were gained from Bina Marga. This table reflected IRI values (column 10) of Kaligawe road on each section. Column 6 and 7 indicate the start and end position for each section where Naasra method was used. Naasra 
method is used to get IRI values. The data used were only the data that reflected deterioration,; it means only the IRI data that was higher on the next stage than on the previous stage. This is according to the IRI value principle: a road experienced an improvement should the IRI value on the previous stage is bigger than on the next stage. The decreasing in roughness value reflects a maintenance or rehabilitation activities that were done on a road; as this research modeled the deterioration rate, data reflected road condition improvement were not used.

Table 1. Condition States

\begin{tabular}{|c|c|c|}
\hline Condition States & IRI Range & Average Value \\
\hline Good & IRI $\leq 3$ & 2 \\
\hline Fair & $3 \leq \mathrm{IRI} \leq 5$ & 4 \\
\hline Poor & $5<\mathrm{IRI} \leq 7$ & 6 \\
\hline Very poor & $\mathrm{IRI}>7$ & 8 \\
\hline
\end{tabular}

Table 2. IRI Data Example

\begin{tabular}{|c|c|c|c|c|c|c|c|c|c|c|}
\hline & & \multicolumn{7}{|c|}{ BINA MARGA } & \multicolumn{2}{|c|}{ ROUGHNESS REPORT } \\
\hline & & \multicolumn{7}{|c|}{ INTERURBAN ROAD MANAGEMENT SYSTEM } & & \\
\hline & & \multicolumn{5}{|c|}{ CENTRAL DATABASE } & \multicolumn{2}{|c|}{2016} & \multicolumn{2}{|c|}{ Jawa Tengah [24] } \\
\hline \multicolumn{4}{|c|}{ Kmpost / Offset } & \multirow{2}{*}{$\begin{array}{l}\text { Length } \\
(\mathrm{km})\end{array}$} & \multirow{2}{*}{\multicolumn{2}{|c|}{$\begin{array}{l}\text { Naasra } \\
\text { St/End }\end{array}$}} & \multirow[t]{2}{*}{$\mathrm{BI}$} & \multirow[t]{2}{*}{$\mathrm{RCI}$} & \multirow[t]{2}{*}{ IRI } & \multirow[b]{2}{*}{ 14-Jun-2016 } \\
\hline \multicolumn{2}{|c|}{ From } & \multicolumn{2}{|l|}{ To } & & & & & & & \\
\hline \multirow{2}{*}{\multicolumn{2}{|c|}{$\begin{array}{l}01613 \mathrm{~K} \\
\text { Stat/Funct }\end{array}$}} & \multicolumn{8}{|c|}{ JLN. KALIGAWE (SEMARANG) } & \\
\hline & & \multicolumn{2}{|c|}{ N A } & & & & & & & \\
\hline \multicolumn{2}{|c|}{ Year: } & 2016 & & Directn & $\mathbf{O}$ & \multicolumn{2}{|c|}{ Method: } & BI & & \\
\hline 0 & 0 & 0 & 17 & 0.017 & 0 & 5 & 5 & & 4.0 & \\
\hline 0 & 17 & 10 & 17 & 0.1 & 5 & 32 & 27 & & 4.2 & \\
\hline 10 & 17 & 20 & 17 & 0.1 & 32 & 69 & 37 & & 5.4 & \\
\hline 20 & 17 & 30 & 17 & 0.1 & 69 & 87 & 18 & & 3.1 & \\
\hline 30 & 17 & 40 & 17 & 0.1 & 87 & 112 & 25 & & 4.0 & \\
\hline 40 & 17 & 50 & 17 & 0.1 & 112 & 131 & 19 & & 3.2 & \\
\hline 50 & 17 & 60 & 17 & 0.1 & 131 & 161 & 30 & & 4.6 & \\
\hline 60 & 17 & 70 & 17 & 0.1 & 161 & 198 & 37 & & 5.4 & \\
\hline 70 & 17 & 80 & 17 & 0.1 & 198 & 255 & 57 & & 7.9 & \\
\hline 80 & 17 & 90 & 17 & 0.1 & 255 & 353 & 98 & & 12.9 & \\
\hline 90 & 17 & 100 & 17 & 0.1 & 353 & 384 & 31 & & 4.7 & \\
\hline 100 & 17 & 110 & 17 & 0.1 & 384 & 421 & 37 & & 5.4 & \\
\hline
\end{tabular}

\subsection{Development of Transition Probability Matrices( TPM )}

Some authors used homogenous Markov Chains to model pavement deterioration (Carnahan1988). There are factors that influence road deterioration such as traffic load, environment and sub grade strength, and therefore should use different kind of TPMs, resulting in non stationary Markov
Chains, which is more realistic (Hong and Wang 2003). However, greater effort and time are needed to obtain a specific matrix for each transition (Perez-Acebo et al. 2017). As this paper used homogenous Markov Chains, therefore some transitions in a certain cycle time were calculated by means of the same TPM. 
The development of TPM was started by using IRI data on June'16 and December'16. The IRI value for each section of the road was analyzed. The data used are the IRI value of the sections on June'16 that experienced an increase on December' 16.

Transition Probability Matrix (TPM) usually denoted with $P . P$ is the transition matrix that reflects the transition from stage 0 to $1 . P$ denotes as:

$$
P=\left[\begin{array}{cccc}
p_{11} & p_{12} & \cdots & p_{1 n} \\
p_{21} & p_{22} & \cdots & p_{2 n} \\
\vdots & & \ddots & \vdots \\
p_{n 1} & p_{n 2} & \cdots & p_{n n}
\end{array}\right]
$$

Matrix $P$ is a squared matrix, with $\boldsymbol{n}$ rows and $\boldsymbol{n}$ columns, where $\boldsymbol{n}$ is the number of considered states.

The $\mathrm{p}_{12}$ itself denotes the transition from state 1 to state $2, \mathrm{p}_{23}$ denotes the transition from state 2 to state 3 and so on, or can be stated as $p_{i j}$, that is the probability of changing from state $\boldsymbol{I}$ to state $\boldsymbol{j}$ in one cycle time. The probability of $\mathrm{p}_{\mathrm{ij}}$ can be calculated using equation below:

$\mathrm{p}_{\mathrm{ij}=} \operatorname{prob}[\mathrm{X}(\mathrm{t}+1)=\mathrm{j} / \mathrm{X}(\mathrm{t})=i] \ldots(1)$

$\mathrm{X}(\mathrm{t})$ is condition state at stage $t$, while $\mathrm{X}(\mathrm{t}+1)$ is condition state at stage $\mathrm{t}+1 . t$ is unit of time, it can be one year, half-year, a week, two weeks, etc. According to Wang et al. 1994, TPM elements of the matrix must meet the following restrictions:

$0 \leq p_{i j} \leq$, for all $i$ and $j$, and $i, j=0,1,2, . ., \mathrm{n} \ldots$ (2)

$\sum_{\mathrm{i}}^{\mathrm{n}} \mathrm{p}_{\mathrm{ij}}=1$, for all $\mathrm{i}$ and $\mathrm{i}=0,1,2 \ldots \mathrm{n}$

As the modeling is about the deterioration, the IRI values that are included in the TPM were those for $\mathrm{p}_{\mathrm{ij}}$ where $\boldsymbol{j}$ is greater than $i$. The value will be 0 for $\mathrm{p}_{\mathrm{ij}}$ whose $\boldsymbol{i}$ is greater than $\boldsymbol{j}$, as it reflects improvement, not deterioration. The $\mathrm{p}_{\mathrm{nn}}$ element reflects a condition that remain the samein the next stage and it is equal to 1 , it expresses that a section will remain on its worst condition and can not deteriorate further (withoutM\&R work). Therefore the deterioration matrix is:

$$
P=\left[\begin{array}{ccccc}
p_{11} & p_{12} & p_{13} & \cdots & p_{1 n} \\
0 & p_{22} & p_{23} & \cdots & p_{2 n} \\
0 & 0 & p_{33} & \cdots & p_{3 n} \\
\vdots & \vdots & \vdots & & \vdots \\
0 & 0 & 0 & \cdots & 1
\end{array}\right]
$$

There are various methods to estimate the probabilities within the matrix $P$, but two techniques are the most employed, they are historical data or experts' knowledge (Tabatabaee and Ziyadi 2013).

This paper used historical data to estimate the probabilities within matrix $P$. The probability for each transition, $\mathrm{p}_{\mathrm{ij}}$, was calculated by:

$$
p_{i j}=\frac{N_{i j}}{N_{i}} \ldots(4)
$$

Where $\mathrm{N}_{\mathrm{ij}}$ is the number of road sections that shift from state $i$ to state $\boldsymbol{j}$ during one cycle time, and $\mathrm{N}_{\mathrm{i}}$ is the total number of sections that were in state $\boldsymbol{i}$ before the transition.

\subsection{Performance Prediction}

Pavement performance prediction can be described by a state vector. A state vector (A) describes the state proportions of the road. The $A_{0}$ is a present state vector, a vector that denotes the present condition of a pavement. Perez-Acebo et al. 2017 give an example: an index ranging from 10 to 0 is divided into five condition stages: 10.0-8.0; 7.9-6.0; 5.9-4.0; 3.9-2.0; 1.9-0. Should the current condition index of the road shows $45 \%$ of the sections has an index value in 10.0-8.0 range; $30 \%$ in 7.9-6.0 and $25 \%$ in 5.9-4.0, the present state vector of the road is: 
$\mathrm{A}=\left\{\mathrm{a}_{1}, \mathrm{a}_{2}, \ldots \mathrm{a}_{\mathrm{i}}, \ldots \mathrm{a}_{\mathrm{n}}\right\} \ldots(5)$

Therefore the $\mathrm{A}_{0}=\{0.45 ; 0.30 ; 0.25 ; 0$; $0\}$.

State vector in any future time, $t$, or after $t$ transitions can be calculated by applying equation (6) below $t$ times(ChapmanKolmogorov equations):

$$
\begin{aligned}
A_{t} & =A_{t-1} x P=A_{t-2} x P x P \\
& =A_{t-2} x P^{2}=A_{t-3} x P^{3}=\cdots=A_{0} x P^{t} \ldots(6)
\end{aligned}
$$

There will be two kinds of performance predictions on this paper, this first one was intended to compare the real data gained to the prediction data, this analysis using June'16 to December'17 IRI data. The second one was to predict the IRI data using July'17 data. These performance predictions used assumption that there were no $M \& R$ works within the analyzed time.

\section{Result and Discussion}

IRI data gained from Bina Marga were used to develop TPM. Table 3 shows the TPM based on June'16 data.

Data in June'16 were also used to form the initial state vector, that is: $\mathrm{A}_{0}=\quad\{0.073171 ; \quad 0.658537$; $0.268293 ; 0\}$.

By applying equation (1) we can find the next state vector. Figure 1 shows the comparison between the real and predicted data using IRI data on June 2016. June'16 is stage 0 , while stage 1 is December' 16 and stage 2 is July' 17 .

Figure 1 compares these data :

1. The average of IRI value of the no $M \& R$ work sections. Denoted as 'Average IRI of no $M \& R$ Sections'.
2. The 'No M\&R Sections' Vector'. This value can be obtained by applying equation below:

$$
I R I_{\text {Average }}=a_{2} \cdot 2+a_{3} \cdot 4+a_{4} \cdot 6+a_{5} \cdot 8
$$

Where $a_{2}, a_{3}, a_{4}, a_{5}$ are the elements of the state vector, as indicated in equation (7) (PerezAcebo et al. 2017). The value of 2, 4, 6 and 8 are the average values as stated in Table. 1 .

3. 'The Predicted IRI' values were based on June'16 data. These values can be obtained by finding the predicted state vectors of the 'No M\&R' sections and then applying equation (7).

\section{Standard Deviation}

Standard deviation can be calculated using equation (8):

$$
S D=\sqrt{\frac{\sum_{i}^{n}\left(x_{i}-\bar{x}\right)^{2}}{n}} \ldots(8)
$$

In stage 0 and 1 the 'Predicted IRI' values were close to the real data, that is the 'Avg. No M\&R IRI' and 'No M\&R Sections IRI', it wasalso within the average $+\mathrm{SD}$ and average-SD, but in the stage 2 the value of the 'Predicted IRI' was not that close to the 'Avg. No M\&R IRI' and 'No M\&R Sections IRI', although the value was still within the average $+\mathrm{SD}$ and average-SD. The 'Predicted IRI' value in stage 2 was even closer to the average e+ SD. It was because the 'Prediction IRI' value did not take into account the IRI data after the M\&R work done after December'16; the prediction only relied on June'16 data. The accuracy on stage 2 was only $86.88 \%$ from the real data. It was so, because the real data (the 'Avg. No MR 
IRI') was 4.39; while the 'Predicted IRI' was 4.9656 .

The 'Avg. No M\&R IRI' and 'No M\&R Sections IRI' both show descending trend after stage 2 ; it was because the IRI values in stage 2 (December'17) are less than the IRI values in stage 1(June'17); this is because the pavement conditions in December' 17 were in better condition than in June'16; it was true because according to the Bina Marga information, there were road reconstruction and level uprising for 50 $\mathrm{cm}$ in October'17. Those works were on the KM 3: 700 to KM 6: 400 with the total of 20 segments, every segment is 5 meter long and 3.75 meter wide.

Figure 2 shows the predicted IRI values using data on July'17 for the next two semesters(December'17 and June'18). This prediction was made with an assumption that there were no $M \& R$ works between July'17and June'18.

The graph shows an ascending trend, which means the predicted IRI values are getting greater than the previous cycle time. It means the road condition is getting worse. This trend is applicable should there is no $M \& R$ work during the predicted time.

The graph denotes the predicted average of IRI value of no $M \& R$ sections. The values in Figure 2 were calculated using equation (7).

Table 4 shows the predicted number of sections in two stages after the first stage (July'17). The prediction of the number of section in every condition was obtained by multiplying the number of no M\&R sectionby the each element of the state vector.

For example : the number of no $M \& R$ work section in June' 18 was 51 and $\mathrm{A}_{2}$ is the state vector for June'18. The state vector of $A_{2}$ is $\{0 ; 0.39706 ; 0.47059$;
$0.09314\}$. It means there was $0 \%$ pavement was in Good condition in June'18; $39.706 \%$ was in Fair condition; $47.059 \%$ was in Poor condition and $9.314 \%$ was in Very Poor condition. The prediction of the number of section in June'18 will be :

Good : 0x51 = 0 sections

Fair : $0.39706 \times 51=20.25$ sections

Poor : $0.47059 \times 51=24$ sections

Very Poor : $0.09314 \times 51=4.75$ sections

This prediction had an assumption of no $M \& R$ work from July'17 to June'18. The analysis showed that the prediction did not have $100 \%$ accuracy, as one can see the total number of pavement section in June'18 was $20.25+24+4.75=49$, while there were a total of 51 of no M\&R work sections in real. The analysis found that if the analysis was continued to the next stage and after, the accuracy of the prediction would be decreasing - the gap of the number of the real no $M \& R$ work sectionsand the total number of the predicted onewas getting biggerthat was why the analysis was limited only until the next two cycle time. New IRI data should be gathered to make a new analysis for the next cycle of time(s) to maintain a good accuracy (more than 90\%). 
Table 3. Total Number of Transition from June'16 to December'1

\begin{tabular}{|c|c|c|c|c|c|}
\hline \multirow{2}{*}{$\begin{array}{c}\text { Number of } \\
\text { Section in each } \\
\text { CS }\end{array}$} & \multirow{2}{*}{$\begin{array}{c}\text { Prior } \\
\text { CSs }\end{array}$} & \multicolumn{4}{|c|}{ Number of Sections in each CS after one cycle time } \\
\hline & & $j=1$ & $j=2$ & $j=3$ & $j=4$ \\
\hline \multirow[t]{2}{*}{3} & \multirow[t]{2}{*}{$\mathrm{i}=1$} & 2 & 1 & 0 & 0 \\
\hline & & 0.666666667 & 0.333333333 & 0 & 0 \\
\hline \multirow[t]{2}{*}{27} & \multirow[t]{2}{*}{$\mathrm{i}=2$} & 0 & 18 & 8 & 1 \\
\hline & & 0 & 0.666666667 & 0.296296296 & 0.037037037 \\
\hline \multirow[t]{2}{*}{11} & \multirow[t]{2}{*}{$\mathrm{i}=3$} & 0 & 0 & 9 & 2 \\
\hline & & 0 & 0 & 0.818181818 & 0.181818182 \\
\hline \multirow[t]{2}{*}{0} & \multirow[t]{2}{*}{$\mathrm{i}=4$} & 0 & 0 & 0 & 0 \\
\hline & & 0 & 0 & 0 & 0 \\
\hline
\end{tabular}

The green-shaded parts depict the Transition Probability Matrix.

Transition Probability Matrix $=P_{\text {June'16toDec. } 16}=\left[\begin{array}{cccc}0.6666667 & 0.33333 & 0 & 0 \\ 0 & 0.66667 & 0.296296 & 0.370370 \\ 0 & 0 & 0.81818 & 0.818182 \\ 0 & 0 & 0 & 0\end{array}\right]$

State Probability Vector at the first stage $=A_{0}=\{0.073171 ; 0.658537 ; 0.268293 ; 0\}$

Table 4. Total Number of Transition from December'16 to July'17

\begin{tabular}{|c|c|c|c|c|c|}
\hline \multirow{2}{*}{$\begin{array}{c}\text { Number of Section } \\
\text { in each CS }\end{array}$} & \multirow[b]{2}{*}{ Prior CSs } & \multicolumn{4}{|c|}{ Number of Sections in each CS after one cycle time } \\
\hline & & $j=1$ & $j=2$ & $j=3$ & $j=4$ \\
\hline 2 & $\mathrm{i}=1$ & 1 & 1 & 0 & 0 \\
\hline \multirow[t]{2}{*}{6} & $i=2$ & 0 & 4 & 2 & 0 \\
\hline & & 0 & 0.666666667 & 0.333333333 & 0 \\
\hline 5 & $i=3$ & 0 & 0 & 5 & 0 \\
\hline \multirow[t]{2}{*}{2} & $i=4$ & 0 & 0 & 0 & 2 \\
\hline & & 0 & 0 & 0 & 1 \\
\hline
\end{tabular}

$\mathrm{P}_{\text {Dec.'16toJuly'17 }}=\left[\begin{array}{cccc}0.5 & 0.5 & 0 & 0 \\ 0 & 0.6667 & 0.3333 & 0 \\ 0 & 0 & 1 & 0 \\ 0 & 0 & 0 & 1\end{array}\right]$

$A_{0}=\{0.1333 ; 0.4 ; 0.3333 ; 0.1333\}$

Table 5. Total Number of Transition from July'17 to December'17 


\begin{tabular}{|c|c|c|c|c|c|}
\hline \multirow{2}{*}{\multicolumn{2}{|c|}{ Number of Section in each CS }} & \multicolumn{4}{|c|}{ Number of Sections in each CS after one cycle time } \\
\hline & & \multirow{2}{*}{$\frac{j=1}{0}$} & \multirow{2}{*}{$\begin{array}{c}\mathrm{j}=2 \\
3\end{array}$} & \multirow{2}{*}{$\begin{array}{c}\mathrm{j}=3 \\
0\end{array}$} & \multirow{2}{*}{$\begin{array}{c}\mathrm{j}=4 \\
0\end{array}$} \\
\hline 3 & $i=1$ & & & & \\
\hline & & 0 & 1 & 0 & 0 \\
\hline \multirow[t]{2}{*}{40} & $\mathrm{i}=2$ & 0 & 27 & 13 & 0 \\
\hline & & 0 & 0.675 & 0.325 & 0 \\
\hline \multirow[t]{2}{*}{8} & $i=3$ & 0 & 0 & 6 & 2 \\
\hline & & 0 & 0 & 0.75 & 0.25 \\
\hline \multirow[t]{2}{*}{0} & $i=4$ & 0 & 0 & 0 & 0 \\
\hline & & 0 & 0 & 0 & 0 \\
\hline
\end{tabular}

$\mathrm{P}_{\text {July'17toDec. } 17}=\left[\begin{array}{cccc}0 & 1 & 0 & 0 \\ 0 & 0.675 & 0.325 & 0 \\ 0 & 0 & 0.75 & 0.25 \\ 0 & 0 & 0 & 0\end{array}\right]$

$A_{0}=\{0.058824 ; 0.784314 ; 0.156863 ; 0\}$

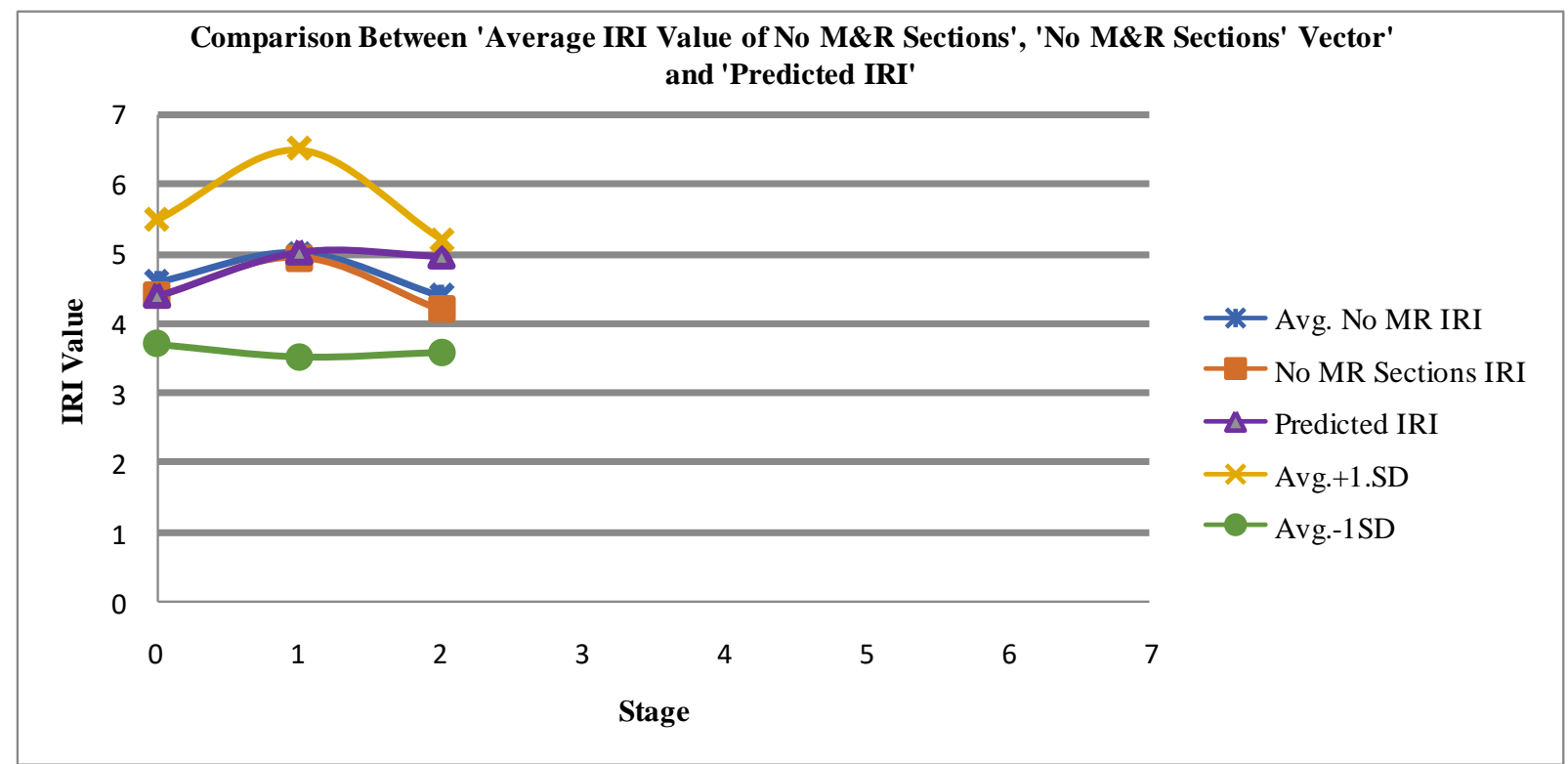

Figure 1. Comparison Between 'Average IRI Value of No M\&R Sections', 'No M\&R Sections' Vector' and 'Predicted IRI' 


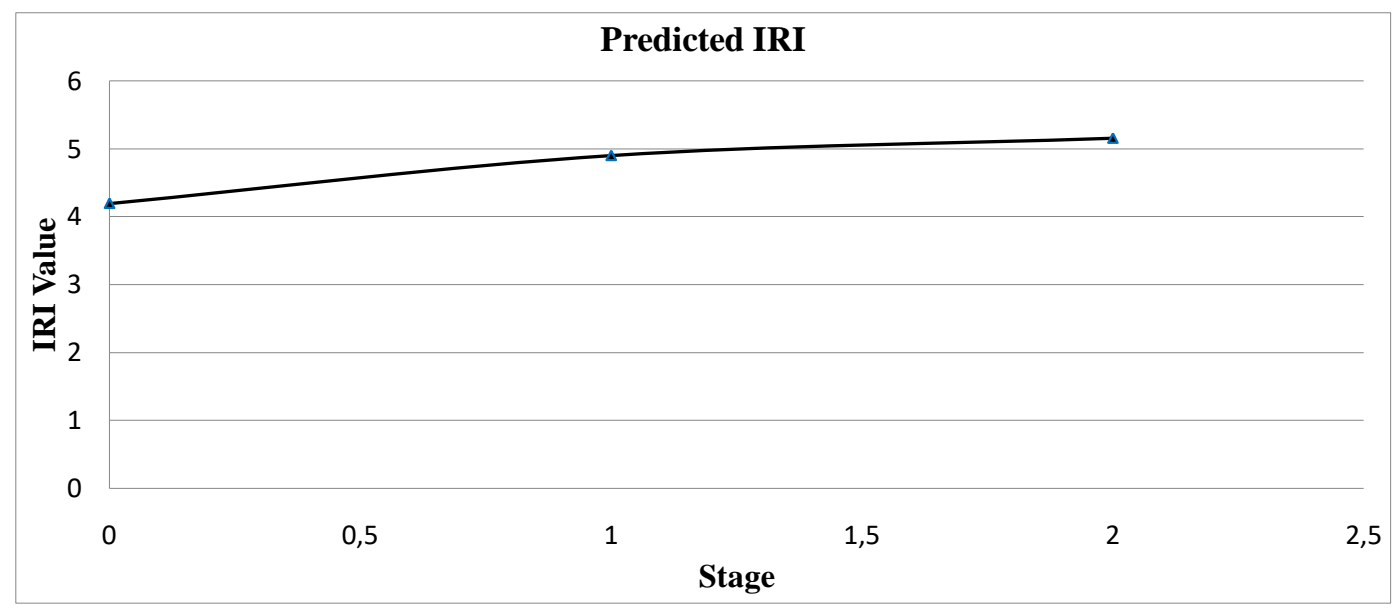

Figure 2. Predicted IRI Values

Table 6. Predicted Number of Section

\begin{tabular}{|c|c|c|c|c|}
\hline \multirow{2}{*}{ Stage } & \multicolumn{4}{c|}{ No of Deteriorate Section } \\
\cline { 2 - 5 } & Good & Fair & Poor & Very Poor \\
\hline July' 17 & 3 & 40 & 8 & 0 \\
\hline December' 17 ( Prediction) & 0 & 30 & 19 & 2 \\
\hline June' 18 (Prediction ) & 0 & 20.25 & 24 & 4.75 \\
\hline
\end{tabular}

Table 4 was the result of Markov formulation and based on an assumption that no $\mathrm{M} \& \mathrm{R}$ works conducted between July'17 until June'18. Table 4 shows that the 'Good' states in July'17 (when the survey was done) did no longer exist in December' 17 and the 'Fair' state experienced a decreasing trend from July'17 to December'17. On the other hand, the 'Poor' and 'Very Poor' state showed an increase from July'17 to December' 17 , they were 8 to 19 sections and 0 to 2 sections, respectively. Based on the number of condition state fluctuation from July'17 to December' 17 we can infer that there were more deteriorating sections within the time interval. Based on our data from Central Java Bina Marga National Road Planning and Monitoring Work Unit, there were 51 sections in July'17, so the rate of deterioration from July'17 to December'17-based on the number of 'Poor' and 'Very Poor' sections was $25 \%$.

Markov formulation prediction also showed an increase of the number of 'Poor' and 'Very Poor' section from December'17 to June'18. The rate was $15.2 \%$. Although the rate seemed to be lower than the July'17 to December'17 period, the deterioration was actually worse because there were no more 'Good' sections from December'17 to June' 18 and the 'Fair' sections were also kept on decreasing.

Table 6 showed a decreasing trend for 'Fair' sections from July'17 to June'18 (with an assumption of no M\&R for the period), the rate was $39.7 \%$, besides no 'Good' sections left. The rate of deterioration-based on the 'Poor' and 'Very Poor' section number-was $36 \%$. 
The Advantages and Limitations of Using Markov Chains in Pavement Performance Prediction

Markov Chains are widely used to predict the performance of infrastructure facilities in term of stochastic techniques (Micevski et al. 2002). Markov Chains models are based on the concept of probabilistic damage that predicts condition of infrastructure over a period of time (Bogdanoff 1978). According to Morcous (2006), the advantages of using Markov Chains model are : (1) they are able to reflect uncertainty from different sources such as presence of condition assessment errors and inherent uncertainty in deterioration process (Lounis 2000); (2) they account for the present condition in predicting the future condition (Madanat et al. 1995); and (3) they can be implemented on networks with large number of facilities because they are efficient to compute and simple to use (Morcous and Rivard 2003).

Nevertheless, these models also have limitations that may affect the reliability of their predictions (Morcous 2006). The limitation of Markov Chains model particularly deals with : (1) the variation of inspection and discrete condition state assumption and (2) the use of first-order Markov Chains that assume the future condition of an infrastructure only depends on the present condition and not on its past condition. These two assumptions were made to eliminate the computational complexity and simplify the decision-making process.

Morcous (2006) did a study to evaluate the impact of these assumptions on the reliability of performance prediction models using field data. Morcous (2006) used field data to develop Markov Chains model for predicting the performance of bridge deck systems. Discrete Markov Chains models usually assume a fixed time intervals of inspections, however some infrastructures, such as bridge sometimes requires variation in inspection periods due to the severity of the infrastructure and the relative costs and benefits associated with performing these inspections on time (Smilowitz and Madanat 2000). The first developed performance prediction models were then adjusted for the variation in the inspection periods; and then compared the first predicted performance models and the adjusted ones. Morcous (2006) utilized field data used earlier in developing transition probability matrices and applied conditional probability rule known as Bayes' rule to adjust the performance prediction models. The difference between the unadjusted and the adjusted models can be seen from the time of the bridge reach a certain condition as illustrated in Figure 3. Figure 3 shows that to reach condition state equal to 3 , the difference between the unadjusted and adjusted models is 7 years that represents $19 \%$ of the predicted service life, while to reach condition state equal to 2 , the difference is 13 years, which represents $22 \%$ of the predicted service life. The percentage errors show that the transition probabilities should be adjusted for the inspection variation periods in order to obtain reliable performance prediction.

Morcous (2006) also evaluated the validity of state independence assumption by using simple frequency test and inference test. By using simple frequency, Morcous (2006) showed that the state independence assumption is in compliance with the test. Table 7 shows the comparison transition sequences of MCR in bridge deck systems. The table shows a comparison of MCR transition sequences of $(5,5 \mid 6)$ versus $(5,5 \mid 5)$, which is termed 'Case 1' and $(4,4 \mid 5)$ versus $(4,4 \mid 4)$ which is termed 'Case 2'. In Case $1,91,1 \%$ of the deck elements with a past condition equal to 6 and a present 
condition equal to 5 have a future condition equal to 5 , while $85,5 \%$ of the deck elements with a past condition equal to 5 and a present condition equal to 5 , have a future condition equal to 5 . In Case 2, 83,4\% of the deck elements with past condition equal to 5 and a present condition equal to 4 , have a future condition equal to 4 , while $82,0 \%$ of the deck elements with a past condition equal to 4 and a present condition equal to 4 , have a future condition equal to 4 . The difference between the two percentages was then calculated, i.e. the difference for the Case 1 is $0.911-0.858=0.0053$ and the difference for the Case 2 is 0.834$0.820=0.014$. The smaller the difference, the better the compliance with the assumption.

Morcous (2006) also conducted inference testing to evaluate the validity of state independence assumption. The result shows that the state independence assumption of Markov Chains can be acceptable for the analysis at the network level, but Morcous (2006) also stated that this assumption may not be acceptable for project level analysis where accurate prediction of element distresses, such as corrosion, cracking and spalling is required.

\section{Conclusion}

Performance prediction modeling can be used to optimize pavement maintenance budgeting, as a prediction of the total resources needed can be predicted by knowing the pavement condition until a period of time

In order to have a good accuracy in prediction between the real data and the predicted ones, a prediction of a pavement condition should take into account new IRI data after a new maintenance, rehabilitation, reconstruction or other works on the pavement within or after the period of the prediction. A new pavement performance prediction should be conducted should there are new M\&R works within the period of a prediction, otherwise the results of the prediction only valid with the pavement condition before the new M\&R works. Assumption(s) during the period of prediction is/are very important as they can explain the possibility of inaccuracy.

From the analysis, the accuracy of the total number prediction of sections with No M\&R works was not $100 \%$, i.e. the total real numbers of No M\&R sections in real is different from the total numbers of the predicted ones, i.e. the total number of sections with No M\&R works in July'17 were 49 sections, while the total number of sections predicted in December' 17 were 51 sections; the gap was 2 sections. The gap was getting bigger when predicting the next cycle of time; that was why the prediction of the number of sections in every condition of the next stage was limited to two next cycle time. In order to have a good accuracy in predicting next section numbers in every condition in the next stage, it is advisable to collect real section numbers in every condition after two cycle time prediction.

The numbers of sections predicted for every condition in December' 17 and June'18 have not been confirmed yet with the real ones for every condition in December' 17 and June'18, as Kaligawe Road was reconstructed in January'18..

To deal with the limitations inherent in Markov Chains models, adjustment should be done when dealing with variation in infrastructure inspections, while refering to Morcous (2006), a more precise methodology in predicting cracking and spalling in rigid pavements should be conducted. Thube (2012) did a study of predicting pavement deterioration using Artificial Neural 
Network (ANN) in a low volume road in India. Thube (2012) proposed some ANN models to predict the distresses of a flexible pavement. The results of the study suggest that the ANN models satisfactorily forecast individual distresses. A study of using Artificial Neural Network in predicting distresses in Kaligawe road can be conducted and then this can be compared to the performance prediction using Markov Chains.

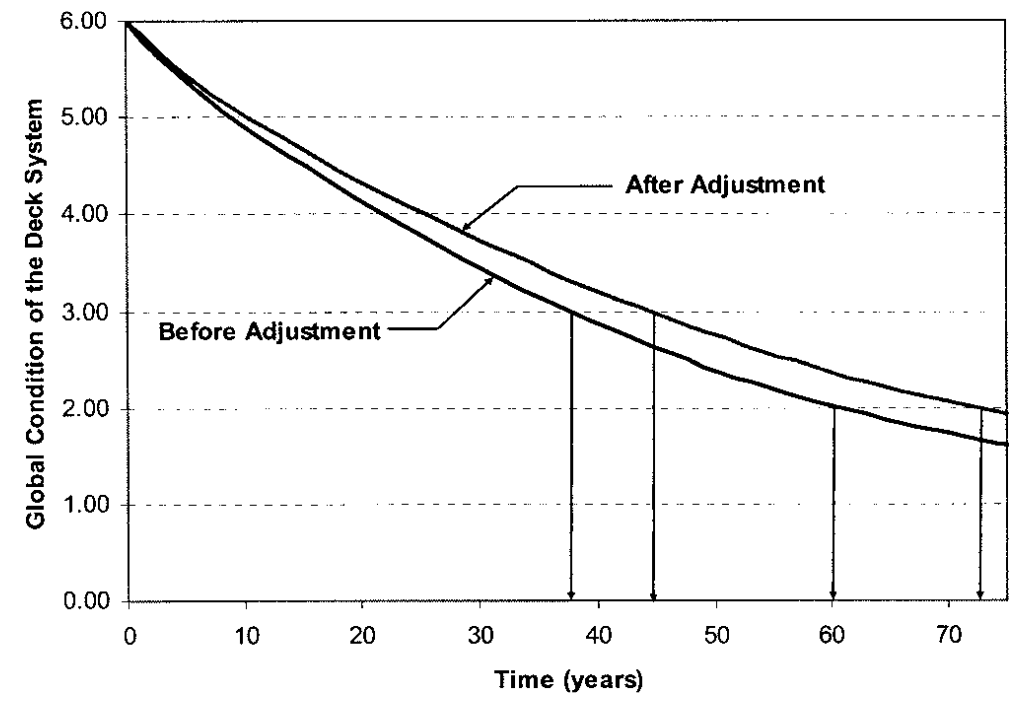

Figure 3. Comparison of Deterioration Curve for Adjusted and Unadjusted Transition Probabilities of Bridge Deck Systems (Source : Morcous 2006)

Table 7. Comparing MCR Transition Sequences (Source : Morcous 2006)

\begin{tabular}{|c|c|c|c|r|r|}
\hline $\begin{array}{c}\text { Case } \\
\text { Number }\end{array}$ & MCR Sequence & Sequence Occurences & $\begin{array}{c}\text { Nonsequence } \\
\text { Occurences }\end{array}$ & Total & $\mathrm{P}(i, j \mid k)$ \\
\hline 1 & $(5,5 \mid 6)$ & 216 & 21 & 237 & 0.911 \\
\hline & $(5,5 \mid 5)$ & 1614 & 267 & 1881 & 0.858 \\
\hline & Total & 1830 & 288 & 223 & 0.834 \\
\hline 2 & $(4,4 \mid 5)$ & 186 & 37 & 555 & 0.82 \\
\hline & $(4,4 \mid 4)$ & 455 & 100 & & \\
\hline & Total & 641 & 137 & & \\
\hline
\end{tabular}

\section{Acknowledgement}

The authorwould like to thank to Central Java Bina Marga National Road Planning and Monitoring Work Unit for providing the data used in this research.

\section{References}

Amin, Md. S. R.(2015).Chapter: The Pavement Performance Modeling: Deterministic vs Stochastic Approaches, In book: Numerical Methods for Multiscale and Multiphysics in Reliability and Safety, 179-196.Switzerland :Springer 
Baik, H. S., Jeong, H. J., \&Abraham, D. M.(2006). Estimation Transition Probabilities in Markov Chains Based Deterioration Models for Management of Wastewater Systems.Journal of Water Resources Planning and Management, 132(1), 15-24.

Carnahan, J.V.(1988). Analytical Framework For Optimizing Pavement Maintenance.Journal of Transportation Engineering, 114 (3), 307-322.

George, K. P., Rajagopal A. S.,\& Lim, L. K. (1989). Models For Predicting Pavement Deterioration, Transportation Research Record : Journal of Transportation Research Board,1215, 17.

Golroo, A., \&Tighe, S. (2009). Use of Soft Computing Application to Model Pervious Concrete Pavement Condition in Cold Climates.Journal of Transportation Engineering, 135(11), 791-800.

Haddadi, S., Coleri, E., \&Wruck, B. (2017). Network-Level Decision Making Tool For Pavement Maintenance and User Safety for Pacific Northwest Transportation Consortium (PacTrans).Final Project Report. Corvallis, Oregon.

Hong, H.P., \&Wang, S.S.(2003). Stochastic Modeling of Pavement Performance.International Journal of Pavement Engineering, 4 (4), 235-243.

Jiang, Y., Saito, M., \& Sinha, K. C.(1988). Bridge Performance Model Using Markov Chains.Transportation Research Record : Journal of Transportation Research Board,1180, 25-32.

Khattak, M.J.,Nur, M. A.,Bhuyan, M. R., \& Gaspard, K.(2014). International
Roughness Index Models for HMA Overlay Treatment of Flexible and Composite

Pavements.InternationalJournal of

Pavement Engineering, 15 (4), 334-344.

Liu, T.(2010). Application of Markov Chains to Analyze and Predict the Time Series, Modern Applied Science, 4(5), 162-166.

Lounis, Z. (2000). Reliability-Based Life Prediction of Aging Concrete Bridge Decks. Life Prediction and Aging Management of Concrete Structures, D. Naus, ed., RILEM, Paris, 229-238.

Madanat, S., Mishalani, R., and Ibrahim, W. H. W. (1995). Estimation of Infrastructure Transition Probabilities From Condition Rating Data. Journal of Infrastructure Systems, 1(2), 120-125.

Madanat, S., Horvath A., \&Reger D. Integration of LCA Into Pavement Management System.

Micevski, T., Kuczera, G., and Coombes, P. (2002). Markov Model for Stormwater Pipe Deterioration. Journal of Infrastructure Systems, 8(2), 49-56.

Morcous, G.(2006). Performance Prediction of Bridge Deck Systems Using Markov Chains, Journal of Performance of Constructed Facilities, 20(2), 146-155.

Morcous, G. and Rivard, H., (2003). Computer Assistance in Managing the Maintenance of Low-Slope Roofs. Journal of Computer in Civil Engineering, 17(4), 230-242.

Perez-Acebo, H., Mindra, N., Railean, A., \& Roji, E.(2017, July). Rigid Pavement Performance Models By Means of Markov Chains With Half Year Step Time.International Journal of Pavement Engineering; 1-14. 
Porras-Alvarado, J. D., Zhang, Z.,\& Salazar, L. G. L.(2014). Probabilistic Approach to Modeling Pavement Performance Using IRI Data, Paper Submitted on Presentation and Publication at the $93^{\text {rd }}$ Annual Meeting of The Transportation Reseach Board, 1-15.

Suman S. K., \& Sinha, S. (2013). Pavement Performance Modeling Using Markov Chains. Proceedings of The

Tabatabaee, N.,Ziyadi, M. (2013). Bayesian Approach to Updating MarkovBased Models for Predicting Pavement Performance, Transportation Research Record :Journal of The Transportation Research Board, 2366, 23-42

Thube D., T. (2012). Artificial Neural Network Based Deterioration Models for Low Volume Road in India. International Journal of Pavement Research and Technology, 5(2), 115-120.
Smilowitz, K., and Madanat, S. (2000). Optimal Inspection and Maintenance Policies for Infrastructure Networks. Computer Aided Civil and Infrastructure Engineering, 120(1), $37-5$

International Symposium on Engineering Under Uncertainty : Safety Assessment and Management, 619-627.

Tighe, S., Li, N., Falls, L. C., \& Haas, R. (2000). Incorporating Road Safety Into Pavement Management. Transportation Research Record : Journal of Transportation Research Board, 1699, 110.

Wang, K. C., Zaniewski, J., \& Way, G. (1994). Probabilistic Behavior of Pavements. Journal of Transportation Engineering, 120(3), 358- 